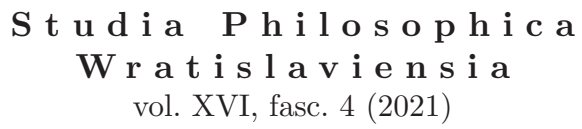

https://doi.org/10.19195/1895-8001.16.4.6

\author{
ANDRZEJ LORCZYK \\ ORCID: 0000-0002-8880-6521 \\ Uniwersytet Wrocławski
}

\title{
Inspiracje aksjologii Elzenberga. Monadologia bez Boga
}

\section{Inspirations of Elzenberg's axiology. A Godless monadology}

\begin{abstract}
The absence of references to Leibniz in almost all of Henryk Elzenberg's writings is surprising, since his first strictly philosophical book was a treatise on Leibniz's metaphysics. Referring to Elzenberg's remarks on the sources of his own thinking and its dependence on others, I will aim at finding Leibnizian traces in Elzenberg's philosophy. By signalling various clues related to Elzenberg's and Leibniz's way of philosophizing and community of beliefs, I will try to show that, although at first not obvious, the deepest trace of Leibniz and the work on his metaphysics can be found within Elzenberg's axiology. I will try to show that Elzenberg's understanding of perfect value (resp. hypervalue) has its structural roots in Leibniz's understanding of the monad (resp. requisite).
\end{abstract}

Keywords: Elzenberg, Leibniz, God, axiology

Nieobecność odwołań do Leibniza w niemal całej twórczości Henryka Elzenberga musi dziwić, pierwszą bowiem jego stricte filozoficzną książką była rozprawa o metafizyce Leibniza. Odwołując się do uwag Elzenberga na temat źródeł własnego myślenia i jego zależności od innych, będę zmierzał do odnalezienia w filozofowaniu 
Elzenberga Leibnizjańskich śladów. Sygnalizując różne tropy związane ze sposobem filozofowania i wspólnotą przekonań Elzenberga i Leibniza, będę starał się też wykazać, że choć zrazu nieoczywisty, najgłębszy ślad Leibniza i pracy nad jego metafizyką daje się uchwycić w obrębie aksjologii Elzenberga. Będę usiłował wykazać, że rozumienie przez Elzenberga wartości perfekcyjnej (resp. hiperwartości) ma swoje źródła strukturalne w rozumieniu przez Leibniza monady (resp. rekwizytu).

Trzy lata po opublikowaniu w Lipsku Arte combinatoria Gottfried W. Leibniz wydał w Królewcu w 1669 roku znaczącą dla polskiej kultury książkę. Dotyczyła ona wyboru Króla Polskiego i ukazała się pod pseudonimem Georgio Vlikovio Lithvano, datowana błędnie na rok 1659 z Wilnem jako rzekomym miejscem wydania ${ }^{1}$. W tym samym, 1669 roku w odpowiedzi na traktat A. Wiszowatego Leibniz wydaje broszurkę pt. Obrona Trójcy za pomoca nowych odkryć logicznych. W roku 1917 w Krakowie została wydana pierwsza polska książka Henryka Elzenberga ${ }^{2}$. Dotyczyła ona metafizyki Leibniza i nie licząc francuskiego doktoratu z Sorbony była pierwszą rozprawą naukową Elzenberga. Poprzedzały ją długoletnie studia nad Leibnizem rozpoczęte bodaj w czerwcu 1912 roku, którym towarzyszyła praca translatorska ${ }^{3}$. Związki Leibniza z Polską, a w szczególności z braćmi polskimi, trwały aż do jego śmierci i znajdowały wielokrotnie wyraz w korespondencji i w publikacjach $^{4}$. Po opublikowaniu rozprawy o metafizyce Leibniza zainteresowanie nim Elzenberga zdaje się słabnąć. Spróbujmy rzecz prześledzić.

„Któryż jest nowoczesny filozof, z którym warto by pomówić w godzinę śmierci?", pytał latem bądź jesienią roku od Narodzenia Pańskiego 1919, a trzydziestym trzecim swego życia Henryk Elzenberg i odpowiadał: „Był w XVII wieku Spinoza i na tym się bodaj skończyło" . Był i Leibniz! Czyż z nim nie godziłoby się „pomówić w godzinę śmierci?" W tym samym roku, wiosną, odnosząc się do zapiski sporządzonej 11 lat wcześniej, notował: „Na lęk śmierci próbowałem już wtedy, a zwłaszcza potem, dwóch jeszcze innych środków. Pierwszym była spekulacja metafizyczna, mająca zachwiać przekonaniem o śmiertelności: całe moje zajmowanie się metafizyką nie ma innego źródła”. A dalej kierując słowa do siebie?, do mnie?, do Ciebie? dodawał: „Pomyśl: stąd płynie i Monadologia, i rzecz o Leibnizu, i odczyt o Kartezjuszu, i to, że dziś jestem kandydatem na katedrę filozofii, i moje u ludzi dziś imię „filozofa”: z lęku przed śmiercią dawno już przezwyciężonego! A drugim — zapytajmy — środkiem? Drugim było pójście na wojnę" ${ }^{6}$.

1 Specimen demonstrationum politicarum pro eligendo Rege Polonorum Novo scribendi genere ad claram certitudinem exactum Auctore Georgio Vlicovio Lithvano Wilnae MDCLIX.

2 H. Elzenberg, Podstawy metafizyki Leibniza, Kraków 1917.

3 G.W. Leibniz, Monadologia, tłum. i komentarz H. Elzenberg, przygotował do druku M. Woroniecki, Toruń 1991, s. III-VIII.

$4 \mathrm{Na}$ ciekawe aspekty wspomnianych relacji wskazuje Ł. Kowalik, Historia braci polskich, „Przegląd Filozoficzny - Nowa Seria" R. 26: 2017, Nr 3(103), s. 254-266.

${ }^{5}$ H. Elzenberg, Kłopot z istnieniem. Aforyzmy w porzadku czasu, Kraków 1963, (lato-jesień 1919), s. 135 (dalej cytuję: H. Elzenberg, Kłopot z istnieniem, data zapisku i strona)

${ }^{6}$ H. Elzenberg, Personalia stoickie i „ascetyczno-moralizatorskie”, [w:] idem, Pisma etyczne, L. Hostyński (oprac.), Lublin 2001, s. 116. 
Wspomniana Monadologia to wydany po raz pierwszy w roku 1991, a przygotowany przed 1916 rokiem przez Elzenberga przekład dzieła Leibniza, a „rzecz o Leibnizu" to opublikowane w 1917 roku Podstawy metafizyki Leibniza. Kończy je Elzenberg słowami:

'The logical argument is short, clear, and on its own premises valid': słowa te Russella (Mind. 198) o niemożliwości interakcji dadzą się zastosować do całości argumentacji logicznej. Zwięzłe i lapidarne, oddają świetnie to wrażenie estetycznego niemal zadowolenia, jakiego każdy umysł łaknący racyonalności doznawać musi na widok wielkiego systemu tak prosto i naturalnie rozwijającego się z jednego założenia ${ }^{7}$.

Konstatując ukazaną w rozprawie przewagę logicznej interpretacji leibnizjańskiej metafizyki nad dynamiczną, pisze: „Ze spinozowską iście konsekwencją wynikają jedno z drugiego twierdzenia, których wzajemna zależność inaczej pozostawała wieczną zagadką" ${ }^{\prime 8}$. Spinoza powołany na świadka właściwego odczytania Leibniza? A przecież Hanowerczyk sam z powodzeniem uprawiał filozofię ordine geometrico. Pisał:

Jeśli teraz określi się przestrzeń, wytyczy drogi i pójdzie za nicią znaczącą ślady węzłami sorytów, wtedy nawet ślepy nie zabłądzi, mimo, że błąka się w labiryncie. Taką nicią jest dla mnie sposób dowodzenia złożony z nieprzerwanego łańcucha rozważań i spleciony z zazębiających się ogniw założeń. Ośmielam się twierdzić, że to ja pierwszy tak piszę ${ }^{9}$.

Dlaczego zatem potrzebny był Spinoza?

Wiosną 1923 roku rozważając stopnie i rodzaje wpływów, przy trzecim stopniu, „przy którym mistrz jednocześnie jest wzorem czy wręcz ideałem, wcieleniem doskonałości", Elzenberg przywołał tytułem przykładu Flauberta i Descartes’a i dodał: „faktycznie jednak (może tu właśnie coś bardziej nieświadomego?) jako wzór surowego myślenia przyświecał mi raczej Spinoza. (To chyba był mój punkt odniesienia gdy kruszyłem kopie o racjonalizm)"10. Dlaczego nie Leibniz i dlaczego o nim głucho?

Latem 1961 roku, wspominając podjętą dwa lata wcześniej pracę nad recenzją książki Russella, Elzenberg zanotował: „Coś się we mnie obudziło z tych czasów, kiedy w Leibnizu uznawałem siebie za 'umysł łaknący racjonalności' i w konsekwentnej budowie podstaw tej metafizyki znajdowałem tak głębokie zadowolenie". Słowa te poprzedzone są dłuższym akapitem, dla którego stanowią ilustrację:

Wiele rzeczy, którymi żyłem, zasnuło mi się mgłą, zbłękitniało; zbyt długo przeżywana, przemyśliwana, niejedna koncepcja straciła swą dawną siłę bodźcową. Cokolwiek jednak w ten sposób przestało być pobudzające, to nie dlatego, bym to odrzucił, ale że, spełniło swa rolę albo raczej: że mi weszło w krew, w styl myślenia, że mnie ukształtowało na tyle, na ile przy oporach 'natury' w ogóle ukształtować mnie mogło. O ile jestem czymś więcej niż samą tylko 'naturą, to jestem dziełem tych wielkich, u których terminowałem, tego, czego mnie nauczyli, — no i swoich osobistych wysiłków, by

7 H. Elzenberg, Podstawy metafizyki Leibniza, s. 70.

8 Ibidem.

9 Specimen demonstrationum politicarum pro eligendo Rege Polonorum Novo scribendi genere ad claram certitudinem exactum Auctore Georgio Vlicovio Lithvano Wilnae MDCLIX; cyt. za: G.W. Leibniz, Wzorzec dowodów politycznych, tłum. T. Bieńkowski, Bydgoszcz 1998, s. 24,

10 H. Elzenberg, Kłopot z istnieniem (17 IV 1923) s. 146-147. 
to wszystko sobie przyswoić i jakoś w sobie ułożyć. Nie ma więc przełomu; jest proces życia. I nie ma odwrócenia się od żadnego mistrza ani ideału: jest wdzięczność ${ }^{11}$.

Wobec Leibniza także? Milcząca?

Wczesną wiosną 1942 roku w Wilnie zapisał Elzenberg w dzienniku: „Mistrzem jest ten, kto pewnej ilości swych bliźnich pomógł wyjść z honorem z opresji życia na ziemi"12. Latem 1944 roku usiłując uchwycić przyczyny, które odwiodły go od racjonalizmu, zanotował:

starałem się zrekonstruować ten proces i jego etapy, od wyraźnej pasji racjonalności jeszcze przy pisaniu Leibniza, stawania po stronie Russella przeciw Bergsonowi, jeszcze po wojnie, poprzez różne fale religijności czy quasi-religijności, zgoła nie nieżyczliwą lekturę świętej Teresy ${ }^{13}$ we wrześniu 1924, aż gdzieś po rok 31, kiedy już stałem na pozycjach biegunowo odmiennych ${ }^{14}$.

Te dwa, trzy fragmenty zawierające imię „Leibniz” niech będą obecne w naszej pamięci. Tym bardziej, że na czterech z górą setkach stron Kłopotu z istnieniem i niespełna trzech Pism etycznych poza wskazanymi miejscami nazwisko Leibniza nie pada, a i tu przywoływane jest przecież tytułem tytułu dzieła Elzenberga. Nie znajdujemy go także w innych publikowanych a także pozostałych w rękopisach i znanych mi dziełach. W Pismach estetycznych występuje jako ten, o którym Bergson miał się wyrazić: „il n'y a gré des vues..., chacune donnée en un block invisible et représentant à se manière le tout de la réalité... — vues intégrales chacune donnée en bloc, chacune indivisible, chacune différente des autres et pourtant représentative de la même chose"15. Te trzy, cztery fragmenty, w których Leibniz przywoływany jest nie w tym charakterze, w jakim występował w Monadologii czy w Podstawach metafizyki, czyli w charakterze autora, a nawet autorytetu, muszą wystarczyć za całą obecność w pozaleibnizjańskiej twórczości Elzenberga.

Niemało już powiedziano o aksjologii Henryka Elzenberga zarówno w tonie apologetycznym, jak i krytycznym. Nie budzą zastrzeżeń związki Elzenberga z całą plejadą Europejskich aksjologów ${ }^{16}$, nawet jeśli są one przez Elzenberga kwestionowane jako wpływy, pozostają z całą pewnością kwestią kongenialności czy ducha epoki. Podobieństwa i różnice były już niejednokrotnie w kręgu uczniów i wnuków Elzenberga przedmiotem uwag i badań. Pozostawiając wszystko to na boku, mając zarazem na względzie wszystko, co uprzednio przywołane i powiedziane, chciałbym tutaj poddać pod rozwagę pewną myśl, która towarzyszy mi od lat wielu i tu, i ów-

11 Ibidem (9 VII 1961) s. 448.

12 Ibidem (28 III 1942) s. 282.

13 Być może jest to zasługą Leibniza, wspominającego w Rozprawie metafizycznej św. Teresę, świątobliwą i wzniosłego ducha, mającą, ,zwyczaj mawiać, że dusza powinna często myśleć tak, jakby jedynie Bóg i ona byli na świecie", G.W. Leibniz, Rozprawa metafizyczna, [w:] idem, Wyznanie wiary filozofa, Warszawa 1969, s. 139.

14 H. Elzenberg, Kłopot z istnieniem (14 VI 1944) s. 332.

15 H. Elzenberg, Ogólność i oryginalność w sztuce. Gtębokość. Sztuka jako objawienie, [w:] idem, Pisma estetyczne, L. Hostyński (oprac.), Lublin 1999, s. 171.

16 Byli w tym kręgu wskazywani także przez Elzenberga: Tadeusz Czeżowski, Nicolai Hartmann, John Laird, Georg George Edward Moore, William David Ross, Max Scheler, Władysław Tatarkiewicz, Wilbur Marshall Urban, by wymienić najznamienitszych, a ograniczając się jedynie do Elzenbergowi współczesnych. 
dzie była wypowiadana - myśl to jednak nie doprowadzona do stanu, który by zadowalał autora, i nie ogłoszona drukiem nawet w anonsie. Był Elzenberg pod dyskretnym urokiem Leibniza tak dyskretnym, że prawie niedostrzegalnym i nie tylko a nawet nie przede wszystkim jako „umysł łaknący racjonalności”. „Pasja racjonalności” podobnie jak „lęk śmierci” odeszły i przebrzmiały zostały przezwyciężone, zwłaszcza ten drugi, i czasami tylko — zwłaszcza ta pierwsza - jak fala nawracają ${ }^{17}$, nie w nich jednak dyskretny urok Leibniza, pod jakim pozostawał Elzenberg, znajduje swój wyraz. Znajduje on swój wyraz w aksjologii Elzenberga, która w swych zasadniczych zrębach jest leibnizjańskiej proweniencji. Wydawać by się mogło, że w świetle rzucanym na dorobek Elzenberga przez przywoływane słowa obstawać przy tej myśli niepodobna, zważywszy zwłaszcza na jej dla Elzenberga nieuchwytność.

Wbrew jednak pierwszemu wrażeniu pozostawia Leibniz, a ściślej jego filozofia i Elzenbergowska jej lektura, dyskretne ślady, które będziemy usiłowali odczytać. Daje się uchwycić, choć poza wykładem Podstaw metafizyki Leibniza i przekładem Monadologii wydaje się nieobecna i nie ujawniana atencja Elzenberga dla Leibniza nie tylko jako autora wykładanego i przekładanego dzieła, lecz także Mistrza, Filozofa, Żywiciela. I nie przeczą temu słowa:

Z żadną duszą nie mam świata wspólnego; z żadną duszą nie jest mi wspólne to co rozjaśnia mi drogę, to z czego biorę polot i życie. I daremnie jest dusz takich szukać: na pięknie, na urokach przeżycia, na grze zwiewnych, wieloznacznych symboli nie oprzemy nigdy żadnej wspólnoty. W żadnej bratniej mi świadomości nic z tego, co ukochałem, nie będzie się odbijało jak w mojej, nie dostąpi życia nowego w miejsce tego, które straci wraz ze mną. Nie tylko ja jestem samotny, ale i mój świat jest samotny śród niezmierzonej ilości światów rozdzielonych nieprzekraczalnym absolutem inności wzajemnej. To jest ta melancholia ogromna, ten ocean smutku rozlany nad oceanem piękności, to co sprawia, że nie można umrzeć radośnie. Jakże więc należy umierać? - z miłościa, miłością tego - że przypomnę i na własny użytek przetworzę znane słowo poety — „czego nigdy nie zobaczą dwie dusze"18.

Akapit ten przywołuje na myśl zdanie Leibniza, możliwe do uznania za streszczenie powyższego wywodu wyrażone zresztą słowami Elzenberga: „Monady nie mają okien, przez które by cokolwiek mogło się do nich dostać lub z nich wydostać"19. I chociaż jest to ślad Leibniza pogłębiony przez Elzenberga, nie w tym jeszcze upatrujemy inspiracji, choć przecież po części płynie ona z Monadologii. Nie upatrujemy jej także w dzielonej przez Elzenberga z Leibnizem otwartości myślenia, gotowości do zmiany własnego stanowiska, poddania się zniewalającej sile argumentów ${ }^{20}$.

Bogusław Paź, podsumowując swój krytyczny wobec rozprawy Elzenberga Podstawy metafizyki Leibniza artykuł, napisał: „W podanej przez Elzenberga interpretacji systemowych pryncypiów metafizyki Leibniza widać pewnego rodzaju — jak to nazwie Witkacy — zanik uczuć metafizycznych, którego rezultatem będzie

17 Paweł Okołowski, dostrzegając w twórczości Elzenberga rys stoicki, konstatuje zarazem: „w jego twórczości wyraźny jest rys Leibnizjański — chłodnej racjonalności...", zob. P. Okołowski Między Elzenbergiem a Bierdiajewem. Studium aksjologiczno-antropologiczne, Warszawa 2012, s. 176.

18 H. Elzenberg Kłopot z istnieniem (22 VIII 1942), s. 298

19 G.W. Leibniz, Monadologia, § 7, s. 48.

20 H. Elzenberg, Kłopot z istnieniem (29 I 1951), s. 355: „W filozofii nie o to chodzi, żeby osiągnąć wynik określony i ostateczny; raczej o coś wręcz przeciwnego: żeby wbrew jednostronnym naciskom, specyficznym dla każdej epoki, wszystkie rozsądne sposoby rozumienia świata pozostawić otwarte". 
ucieczka Elzenberga w aksjologię. Bowiem: »Wartość nie pożąda istnienia« — zanotuje on pięć lat później w swoich notatkach"21. Zgodziwszy się, że jest to exodus, wypada jednak zauważyć, że było to świadome ograniczenie przedmiotu dociekań motywowane trafnym rozpoznaniem własnych uzdolnień i kompetencji. Trafność naszego rozpoznania natury ograniczenia dociekań do obszaru aksjologii poświadczają zanotowane w czasie przygotowywania Podstaw metafizyki Leibniza słowa Elzenberga: ,jestem człowiekiem szukającym absolutu w dziedzinie wartości, tak jak metafizycy w dziedzinie bytu"22. Paweł Okołowski w recenzji tomu $Z$ historii filozofii pism Elzenberga wskazuje na zawartą w Podstawach metafizyki Leibni$z a$ kompetentną rekonstrukcję leibnizjańskiej ontologii, opartą na znajomości także „klasycznych kwestii metafizycznych” jako zapowiedź Elzenbergowskich dokonań konstrukcyjnych i na tym poprzestaje ${ }^{23}$. Także i w tym, choć jesteśmy już blisko sedna, nie upatrujemy zasadniczej leibnizjańskiej inspiracji.

Idzie nam bowiem o aksjologię Elzenberga, zwłaszcza formalną jako pozostającą pod dyskretnym wpływem Leibniza. Bliższy perspektywie, którą tu proponujemy, był Bogusław Wolniewicz. Odsyłając do 33 strony Podstaw metafizyki Leibniza, pisał: „Sam Elzenberg przedstawiajacc tu i komentując poglądy stojącego w tejże tradycji Leibniza, ujął to jako zasadę, że »istoty rozumne wybierają zawsze to co najlepsze "24, przekonany, że zasada ta jest w leibnizjańskiej wersji przyjmowana przez Elzenberga. Ważny to ślad Leibniza, nie stanowi on jednak decydującego argumentu za Leibnizjańską proweniencją aksjologicznych badań Elzenberga. Jak zauważa bowiem Wolniewicz, tradycja, według której rozumnie chcieć można tylko tego, co jawi się chcącemu jako dobro, sięga swymi początkami Sokratesa i Platona ${ }^{25}$. Także wskazywana przez Wolniewicza zbieżność, czy może tożsamość labiryntu wolności Leibniza i labiryntu wartości Elzenberga wyrażona formułą: „wartości są tym, co kieruje działaniami istot wolnych" ${ }^{26}$, nie stanowi racji wystarczającej dla uznania leibnizjańskich inspiracji Elzenbergowskiej aksjologii, dotyczy bowiem w równej mierze aksjologii Kanta.

Jak powszechnie wiadomo ${ }^{27}$, podstawą aksjologii uprawianej przez Elzenberga jest z jednej strony radykalne odróżnienie wartości perfekcyjnej jako wartości w sensie ścisłym, od wartości utylitarnej zwanej wartością jedynie z racji podobieństwa do perfekcyjnej, z drugiej strony związanie wartości w sensie ścisłym z powinnością. Wartości perfekcyjne tym różnią się od wartości utylitarnych, że „domagają się, aby im służyć", podczas gdy utylitarne pozostają na służbie. Wartość nie jest więc ani

21 B. Paź, Rudymenty filozofii G. W. Leibniza w ujęciu H. Elzenberga. Wokót logikalnej interpretacji metafizyki Leibniza, [w:] Człowiek wobec wartości w filozofii Henryka Elzenberga, A. Lorczyk (red.), Warszawa 1998, s. 67. Przywołane zdanie Elzenberga pochodzi z Kłopotu z istnieniem i nosi datę 23 VII 1923.

22 H. Elzenberg, Tragedia i tragizm, [w:] Księga szkiców, Rkps, MHE-181 w oryginalnym układzie Elzenberga teczka nr 19, karta 80 verso (notatka z 4 VIII 1916).

23 P. Okołowski, Między Elzenbergiem a Bierdiajewem, s. 24.

24 B. Wolniewicz, Myśl Elzenberga, [w:] B. Wolniewicz, Filozofia i wartości, Warszawa 1993, s. 94.

25 Ibidem.

26 B. Wolniewicz, Z aksjologii Elzenberga, [w:] idem, Filozofia i wartości, s. 146

27 Pisali o tym wielokrotnie Hostyński, Schrade, Tyburski, Wiśniewski, Wolniewicz, Woroniecki, Zubelewicz i piszący te słowa. 
przedmiotem, ani cechą, lecz zgodnie z określeniem Elzenberga to fakt, że przedmiot jest taki, jaki powinien być, czyli posiada cechy, jakie powinien posiadać. Wartością jest więc zachodzenie relacji „takożsamości” między stanem rzeczy faktycznym a powinnym. Zgodnie z powyższym określeniem wartościowe mogą być przedmioty, czyli rzeczy i osoby, a ich wartość polega na tym, że są takie, jakie być powinny. Nie są natomiast wartościowe ani stany rzeczy, te mogą być jedynie „powinne”, ani cechy, które z kolei mogą być nie wartościowe, lecz wartościotwórcze. Analiza cechy wartościotwórczej prowadzi do wniosku, że w całej strukturze wartości ona właśnie jest elementem pierwotnym. Cecha ta jest różna od wartości, a jej posiadanie przez przedmiot powoduje, że jest on w „powinnym stanie rzeczy”, czyli jest wartościowy.

O cesze tej czytamy w Konstrukcji pojęcia wartości:

Możemy tę cechę nazwać 'wartościodajną' (-wertgebend), - albo może 'wartościotwórczą'. [Rzeczy są 'wertwol' cechy są wertgebend] [Można by również mówić o cesze powinnej — (gesolt?) — jest to cecha, której realizowanie jest celem ostatecznym. Nie jest ona wartością, ani nie posiada wartości, ale jest czymś najwyższym, z czego sama wartość pochodzi ${ }^{28}$.

Cechy te, same nie będąc wartościowe, stanowią warunki bycia wartością, są więc — jak określa je Elzenberg — nadwartościowe, czy też hiperwartościowe. Cecha przysługująca przedmiotowi w sposobie faktycznym i powinnym czyni przedmiot wartościowym. Relacja „takożsamości” zachodząca między faktycznym a powinnym przysługiwaniem cechy przedmiotowi jest wobec niego relacją wewnętrzną. „My bowiem rozumieliśmy wartość - czytamy w Nauce i barbarzyństwie - jako coś niezależnego i od nas, i od takiego czy innego między nami a przedmiotem stosunku, coś co tkwiłoby w przedmiocie i wtedy, gdyby istniał on na świecie sam jeden" 29 , a więc gdyby nie było możliwe zachodzenie jakiegokolwiek stosunku przedmiotu z czymkolwiek poza nim. Byłaby więc wartość jego wyznaczeniem wewnętrznym ${ }^{30}$. Wartość perfekcyjna nigdy nie mogłaby opierać się na wyznaczeniu zewnętrznym.

Cecha wartościotwórcza jest więc tym, bez czego nie może przedmiotowi przysługiwać wartość. Coś jest wartościowe, o ile faktycznie posiada właściwą sobie cechę powinną. Może ich także posiadać wiele. Jeśli faktycznie przedmiot posiada jedną czy wiele cech, jest wartościowy perfekcyjnie, a zatem dobry czy piękny. Można byłoby wyrazić to inaczej. Cecha wartościotwórcza, a właściwie jej faktyczne przysługiwanie przedmiotowi, jest racją dostateczną wartości (dobra względnie piękna) przedmiotu. Takim przedmiotem może być zarówno osoba, jak i jej działanie.

Zestawmy powyższe z następującymi fragmentami Leibniza:

Kiedy więc nie brak racji dostatecznej, by działać tak właśnie, nie brak jej również, by działać tą właśnie drogą, a więc drogi nie są bynajmniej niezróżnicowane. Ilekroć nie brak racji dostatecznych poszczególnego działania, tylekroć nie brak ich dla wszystkich jego rekwizytów. [...] Jakoż sama natura

28 H. Elzenberg Konstrukcja pojęcia wartości, [w:] idem, Pisma aksjologiczne, L. Hostyński, A. Lorczyk, A. Nogal (oprac.), Lublin 2002, s. 92, cytat skorygowano, opierając się na rkps. Elzenberga: III-181 w oryginalnym układzie Elzenberga teczka nr 16, s. 89

29 H. Elzenberg. Wartość i człowiek, Toruń 1966, s. 151.

30 Por. H. Elzenberg, Podstawy metafizyki Leibniza, s. 39-41. Cytat z Primae veritates Leibniza: „Nulla autem datur denominatio pure extrinseca” (s. 41); sformułowanie Elzenberga: „Czyli że nie ma wyznaczeń czysto zewnętrznych” w oryginale łacińskim: „nullas dari denominationes pure extrinsecas" (s. 39) 
rzeczy pokazuje, że każde wydarzenie ma przede wszystkim swoje uwarunkowania, rekwizyty, odpowiadające mu możności, których istnienie stanowi wobec niego rację dostateczną ${ }^{31}$.

Elzenberg odsyła w Podstawach metafizyki Leibniza do tych miejsc polemiki z Clarke'em, znał je zatem ${ }^{32}$. Ślady tej znajomości znajdujemy w Elzenberga koncepcji wartości perfekcyjnej. Podobnie jak rekwizyty stanowią rację dostateczną istnienia, tak cechy wartościotwórcze stanowią rację dostateczną bycia wartościowym względnie dobrym.

Przywołuje także Elzenberg w Podstawach metafizyki Leibniza następujący fragment z rozprawki Prawdy pierwotne metafizyki: „,corpora ab aliis corporibus recedunt vi proprii elastri, non vi aliena, esti corpus aliud requisitum fuerit ut elastrum (quod ab aliquo ipsi corpori intrinseco oritur) agere posset"33. Prawdy pierwotne metafizyki - sześciostronnicowy tekst Leibniza, z którego pochodzi przytoczony powyżej fragment, cytuje Elzenberg na kilku stronach swej rozprawy o metafizyce Leibniza kilkanaście razy. O jego znaczeniu czytamy: „Najważniejsza jest rozprawka Primae Veritates; [...] Ze wszystkich pism Leibniza to w najwyższym stopniu ma charakter systematycznego wykładu jego metafizyki”34. Niepodobna więc, by zarówno rozprawka Leibniza jak i powyższy jej fragment nie pozostawiły w myśleniu Elzenberga śladu. Przywołajmy jeszcze jeden fragment z doskonale znanej Elzenbergowi rozprawki Leibniza:

Albowiem, żeby pominąć milczeniem to, iż nie da się wytłumaczyć, jak z jednej rzeczy przedostaje się coś do substancji innej rzeczy, wykazane już zostało, że z pojęcia każdej rzeczy wynikają od razu wszystkie jej przyszłe stany i że wedle wymogów ścisłości metafizycznej to, co nazywamy przyczynami, to są tylko współtowarzyszące rekwizyty ${ }^{35}$.

By zdać sobie sprawę ze znaczenia i miejsca rekwizytów w filozofii Leibniza posłużymy się znamienitą rozprawą Jerzego Perzanowskiego Teofilozofia Leibniza. Czynimy tak z uwagi na zawartą w niej systematyczną prezentację teorii rekwizytów i ich miejsca w namyśle Leibniza, mając także na względzie wielokrotnie wyrażaną przez J. Perzanowskiego atencję dla Henryka Elzenberga i jego aksjologicznych dokonań.

A oto zebrane najistotniejsze odnoszące się do rekwizy tów definicje i twierdzenia:

Rekwizytem obiektu jest to, bez czego nie może on istnieć.

Rekwizyty są jakościami.

Racją istnienia obiektu jest zespół jego rekwizytów.

31 G.W. Leibniz, Polemika z S. Clarke'iem. Piąte pismo Leibniza do Clarke'a (powstałe w potowie sierpnia 1716) punkt 17-18, [w:] idem, Wyznanie wiary filozofa, s. 375 (Leibniz odsyła tu do punktu 66 swego pisma.)

32 H. Elzenberg, Podstawy metafizyki Leibniza, s. 40, przyp. 4.

33 Ibidem, s. 26, przyp. 2. Juliusz Domański przełożył przywołany fragment następująco: „ciała oddalają się od innych ciał mocą własnego pędu (elastrum), a nie mocą cudzą, chociaż potrzebne im było inne ciało, aby ten pęd (który powstaje pod wpływem czegoś zewnętrznego w stosunku do samego ciała) mógł działać"; G.W. Leibniz, Prawdy pierwotne metafizyki (powstałe między 1679 a 1716 rokiem), [w:] idem, Wyznanie wiary filozofa, s. 92 (w wydaniu Couturata s. 518-523). Znał więc Elzenberg termin requisitum i jego znaczenie w metafizyce Leibniza. Wydaje się, że w tłumaczenie Domańskiego wkradł się błąd, zamiast zewnętrzny winno być wewnętrzny (intrinseco).

${ }^{34}$ H. Elzenberg, Podstawy metafizyki Leibniza, s. 7, przyp. 1.

35 G.W. Leibniz, Prawdy pierwotne metafizyki, s. 91-92. 
Bytem (ontycznie) koniecznym jest byt, z którego istoty wynika istnienie: causa sui.

Niektóre z monad są bytami koniecznymi.

Jedyną monadą konieczną jest Bóg.

Jest on monadą najdoskonalszą, centralną.

Monady stworzone stworzył Bóg.

[Monady:] W porządku ontologicznym są złożone (są splotami jakości) i stworzone (monada centralna - przez owo splatanie jakości doskonałych, perfekcji, monady pochodne — przez ich psucie) ${ }^{36}$.

Na przełomie 1941 i 1942 roku w warunkach ${ }^{37}$ przywołujących skojarzenie z okolicznościami powstania Rozprawy o metodzie Kartezjusza Elzenberg zanotował:

Bóg osobisty. - Przede wszystkim tego przed sobą nie ukrywajmy: w mojej 'koncepcji' zbawienia tego nie uwzględniam, ale w moich aspiracjach jest wyraźnie obecne marzenie o Bogu osobowym, o wyjściu z samotności i opuszczenia przez obcowanie z takim Bogiem ('dobrym' i 'rozumiejącym'). Nie ma na to miejsca w mojej wizji świata, ale trzeba stwierdzić fakt marzenia, pragnienia. I w tym świetle dążenie do zbawienia [...] w znacznej mierze jest dążeniem od samotności ku obcowaniu (nie bolesnemu jak obcowanie z drugim człowiekiem) $)^{38}$.

Może więc nie był to zanik uczuć metafizycznych, ale świadomość niemożności obstawania przy optymistycznej Leibnizjańskiej wizji świata. W obliczu doświadczeń XX wieku i Elzenberga własnych. Może jedyne co pozostawało to wizja doskonałości bez Monady centralnej, bez Boga Gwaranta ładu wszechświata, harmonii całości. Nie dostrzegając zniewalającej racji w przeprowadzonym przez Leibniza w listach do Clarke'a dowodzie niemożliwości istnienia dwóch substancji posiadających te same rekwizyty, opartym na braku racji, dla której Bóg miałby różnie traktować nierozeznawalne, przywołując jednocześnie w słowach: „Nie widać jednak dlaczegoby Bóg nie miał wybrać obydwóch, albo obydwa potraktować jednakowo, pomijajacc już niewłaściwość powoływania się na Boga u samego początku systemu" — pod-

36 J. Perzanowski, Teofilozofia Leibniza, [w:] G.W. Leibniz, Pisma z teologii mistycznej, Kraków 1994, s. 278-279. Dla wskazania kontekstu przywołajmy parę fragmentów dotyczących rekwizytów z dzieł Leibniza:

„Rekwizytem jest to, bez czego rzecz nie może istnieć.

Rekwizyt jest czymś wcześniejszym z natury, co zawiesza skutek, zwykle nieodzowną przyczyną.

Aby poznać daną rzecz, należy uwzględnić wszystkie rekwizyty tej rzeczy, to znaczy to wszystko, co wystarcza do odróżnienia jej od jakiejkolwiek innej rzeczy; i to właśnie zwie się definicją, naturą, własnością równoważną"; zob. G.W. Leibniz, Wyznanie wiary filozofa, s. 453 przyp. 9. Jak się wydaje, w tłumaczenie wkradł się błąd, rekwizyt może raczej zawierać skutek a nie go zawieszać. W Wyznaniu wiary filozofa czytamy natomiast: [...] sądzę, iż można udowodnić, że nigdy nie ma czegoś takiego, czemu by ktoś (przynajmniej wszechwiedzący) nie mógł wyznaczyć racji dostatecznej, dlaczego to raczej jest, niż nie jest, i dlaczego jest w sposób raczej taki niż inny. Kto temu przeczy, niszczy różnicę między samym bytem a niebytem. Cokolwiek istnieje, z pewnością mieć będzie wszystkie rekwizyty istnienia, a wszystkie rekwizyty istnienia razem wzięte stanowią dostateczna rację istnienia; cokolwiek tedy istnieje, posiada dostateczną rację istnienia", ibidem, s. 7 (powstało w Paryżu w 1673 r.)

37 „Piszę w warunkach fantastycznych: mróz w pokoju, ja w łóżku opatulony, mimo to marznąc, z rękawiczkami na rękach, światło lampy źle pada na papier; nie mam odpowiedniej podkładki, piszę w pozycji wykręconej", notatka z 30 XII 1941, [w:] H. Elzenberg, Zbawienie i ideał w moim ujęciu, Rkps, III-181 w oryginalnym układzie Elzenberga teczka nr 46, karta 1 recto. W 2017 roku cytowany tekst został opublikowany przez B. Wolniewicza i J. Zubelewicza [w:] „Przegląd Filozoficzny — Seria Nowa" R. 26: 2017, Nr. 4(104). Cytuję z rękopisu ze względu na potrzebę odwołania sie do jego cech nieujawnionych w druku.

38 Ibidem, karta 5 verso (notatka z 1 I 1942). 
stawę własnego sprzeciwu, nie przyjmuje Elzenberg zarazem do wiadomości, że bez Boga nie byłoby stworzone nic. Doskonałość pojmowana przez Elzenberga lokalnie ma charakter leibnizjański. Miarą doskonałości istniejącej w ujęciu Leibniza było posiadanie maksymalnej dostępnej ilości rekwizytów i to najlepiej w stopniu doskonałym, czyli perfekcji. Na gruncie Elzenbergowskiej aksjologii miarą wartości przedmiotu jest posiadanie maksymalnej liczby cech wartościotwórczych i to najlepiej w stopniu doskonałym. W obu przypadkach podstawą uporządkowania pod względem doskonałości, czyli uporządkowania hierarchicznego, jest ilość i intensywność odpowiednio rekwizytów i nadwartości. W odniesieniu do wartości poświadczają to słowa Elzenberga: „Wartość', o której tu mowa, to zatem jakby zajmowanie pewnego szczebla w hierarchii; hierarchii nie ustanowionej według jakiegoś swoistego punktu widzenia i ze względu na jakąś swoistą cechę, ale hierarchii jak gdyby par excellence, niezależnej od względów i punktów widzenia, nie stanowionej"39.

W 1676 w grudniu zapisał Leibniz następujący wywód:

Do istnienia jest niezbędna obecność zbioru wszystkich rekwizytów. Rekwizytem jest to, bez czego rzecz nie może istnieć. Zbiór wszystkich rekwizytów stanowi pełną przyczynę rzeczy. Nic nie jest bez racji. Albowiem nie ma niczego bez zbioru wszystkich rekwizytów. W ciałach brak jest racji istnienia. Dowieść można łatwo, że choćbyś się cofał w nieskończoność, będziesz tylko mnożyć ciała, a nie pojmiesz racji, dla jakiej są one raczej na taki a nie na inny sposób. Zbiór wszystkich rekwizytów dowolnego ciała jest poza ciałem. Zbiór rekwizytów jednego ciała i zbiór wszystkich rekwizytów ciała innego tkwi w jednym i tym samym. Czymkolwiek by ono było, owo jedyne coś stanowi ostateczną rację rzeczy. Albowiem to co jest prawdziwe dla ciał, jest prawdziwe dla wszystkiego innego, co nie istnieje z koniecznością, czyli co samo w sobie nie zawiera racji istnienia. Byt konieczny jest jeden jedyny tylko. Byt konieczny zwiera w sobie rekwizyty wszystkich rzeczy ${ }^{40}$.

Istnienie Boga, a także znaczenie rekwizytów zostało objaśnione w przytoczonym fragmencie na podstawie zasady: Nic nie jest bez racji. Jeśli byt konieczny monada centralna, zawiera w sobie wszystkie rekwizyty, jest wiec racją istnienia wszystkiego, bez Boga nic istnieć nie będzie. A jeśli nie ma Boga, jeśli — jak chciał Elzenberg — nie ma dla Niego miejsca w wizji świata, wizji zbawienia, to czy wszystko wolno? A może trzeba, uznając ten brak, szukać doskonałości i harmonii w porządku już nie bytu będącego zarazem dobrem, lecz dobra nie domagającego się bytu. Dobra, którego nie gwarantuje Bóg? Na podobieństwo aksjologii z teorią transcendentaliów, a więc i rozumienie powinności jako modi entis wskazywał Czeżowski ${ }^{41}$. I choć sam Elzenberg odrzucał taką interpretację, wskazywał zarazem na

39 H. Elzenberg, Pojęcie wartości i powinności. Tekst żemłosławski, [w:] idem, Pisma aksjologiczne, s. 129. Cytat skorygowano na podstawie rkps. III-181 w oryginalnym układzie Elzenberga teczka nr 16, karta 10.

40 G.W. Leibniz, Wyznanie wiary filozofa, s. 454-455, przyp. 14

41 „Uważam, że wartości są transcendentaliami, ale cóż to są transcendentalia? To są takie sposoby orzekania, które leżą poza zakresem kategorii, tzn. które nie determinują kategorii; z innego punktu widzenia - nie są one cechami przedmiotów, lecz charakteryzują strukturę przedmiotu indywidualnego nie wchodząc w skład tej struktury. Są to modi entis, które w jakiś sposób dotyczą sposobu wiązania się własności w obrębie indywiduum, ale które same własnościami nie są. To w dostateczny sposób charakteryzuje stosunek bytu do wartości, jeżeli przez byt będę rozumiał przedmiot indywidualny”, wypowiedź Czeżowskiego w dyskusji na łamach „Znaku” 130 (1965), s. 438. 
logikę systemu jako domagającą się takiego właśnie rozumienia. Przez powinność jako modi entis porządek bytu sprzężony jest z porządkiem wartości.

Brak Monady Centralnej w myśleniu Elzenberga zmusza go do poszukiwania innego fundamentu porządku wartości i samej wartościowości. Znamienne, że badając wartość perfekcyjną w jej aspekcie wpływania na człowieka i jego działanie, odnosi się Elzenberg do hiperwartości, a następnie odsyła do Nieokreślonego jako ich źródła. W rozważaniach zatytułowanych Motywacja etyczna czytamy:

Do tego dochodzi pewien ton religijny (może właśnie przy motywacji niezbędny, a to dzięki temu, że przedmiotem kontemplacji jest nie tylko wartość, ale i 'nadwartość' cechy: coś co jest dla nas pojęciowo mniej więcej już niezrozumiałe. (A wyższe niż wartość! Jesteśmy tu już bliscy sfery Nieokreślonego??) ${ }^{42}$.

Nawet jeśli uznać, że Nieokreślone pozostaje w aksjologii Elzenberga w takim samym odniesieniu do hiperwartości, wartości, a dalej przedmiotu wartościowego, jak Bóg do rekwizytów, monad, a dalej substancji, w monadologii Leibniza, nie oznacza to tożsamości tych odniesień a jedynie ich — używając zwrotu Elzenberga — t akożsa mość. Odmienność porządku ontycznego (resp. ontologicznego) od aksjotycznego (resp. aksjologicznego) nie pozwala uznać aksjologii za wersję monadologii. Dopuszcza jedynie wskazanie na ten sam rys myślenia i jego strukturalne podobieństwo. By uwydatnić różnicę przywołajmy jeszcze jeden fragment z Teofilozofii Leibniza:

Do istnienia, czyli do ustanowienia współmożliwości z Bogiem i z innymi obiektami istniejącymi, konieczne jest bowiem, by nastąpiło „połączenie wszystkich rekwizytów”, to jest by zadziałały razem te wszystkie czynniki, bez których obiekt nie mógłby zaistnieć.

Jakości są uporządkowane z uwagi na porządek ontologiczny, w którym byty mniej doskonałe poprzedzają byty doskonalsze. Porządek ten jest więc porządkiem doskonałości.

Doskonałości bądź perfekcje to jakości w pełni respektujące porządek doskonałości. Są one jakościami pozytywnymi, absolutnymi i prostymi.

Pozostałe jakości otrzymane są z jakości doskonałych przez ich psucie, pomniejszanie. Niedoskonałość polega na ograniczeniu.

Byt najdoskonalszy, Bóg, jest podmiotem wszystkich perfekcji.

Jest on bytem koniecznym, bo rekwizytami jego istnienia są jego własne doskonałości.

Istnienie jest doskonałością. Byt najdoskonalszy więc istnieje.

Każda rzecz czyni stosownie do rozmiarów swej doskonałości starania, by zaistnieć ${ }^{43}$.

W perspektywie aksjologii Elzenberga ostatnie zdanie mogłoby odnosić się do powinności rozumianej jako domaganie się bycia doskonałym, powinności bycia takim a takim, doprowadzenie do „takożsamości” faktycznego i powinnego stanu. Spróbujmy tytułem podsumowania sformułować na wzór leibnizjański parę definicji i twierdzeń aksjologicznych. Uczynimy to, używając terminologii Leibniza i Elzenberga:

Rekwizytem aksjologicznym jest to bez czego rzecz lub osoba nie może być wartościowa, czyli dobra bądź piękna.

Rekwizytem aksjologicznym jest cecha wartościotwórcza, hiperwartość.

42 H. Elzenberg, Motywacja etyczna (wartość w religii i kulturze) (przełom 1943 i 44 roku), ,Studia Filozoficzne" 12 (1986), s. 13. Por. moje uwagi w O nadwartości, powoinności i sensie. Prolegomena rekonstrukcji późnej aksjologii Elzenberga, [w:] Człowiek wobec wartości, s. 93-130.

43 J. Perzanowski, Teofilozofia Leibniza, s. 323-324. 
Rekwizyt aksjologiczny doskonały to perfekcja, hiperwartość w stopniu maksymalnym.

Cecha wartościotwórcza może być w większym lub mniejszym stopniu a zatem przysługiwać czemuś w mniejszym lub większym natężeniu przyczyniając się do tego, że coś jest mniej czy bardziej wartościowe.

Rzecz lub osoba może posiadać mniej czy więcej rekwizytów aksjologicznych i każdy w mniejszym bądź większym stopniu, w skrajnym przypadku jako doskonałość, czyli perfekcję (hiperwartość). Stanowi to o doskonałości rzeczy czy osoby (monady).

Monada posiadajacca wszystkie rekwizyty w stopniu doskonałym, czyli wszystkie perfekcje to monada centralna, Bóg. Ponieważ sfera wartości jest sferą niepełnej rzeczywistości, naznaczona jest niedoskonałością. Nie może więc być właściwa dla Boga.

Według Leibniza wszystkie inne monady powstają przez psucie. Powstają w sposób nagły, czyli są stwarzane.

Jako że Elzenberg nie dopuszcza możliwości istnienia Boga i aktu stworzenia, można rzec, że aksjologia Elzenberga to w pewnym sensie monadologia bez Monady Centralnej bez istnienia i bez stworzenia monad. Aksjologia jest więc zamiast ontologii i niejako obok niej. Jest próbą budowania fundamentu dla dobra, gdy ten fundament - zwłaszcza jako istniejący — uległ erozji. Jest więc jego rekonstrukcją, ale czy udaną?

Ostatnim śladem Leibniza w aksjologii Elzenberga zdaje się terminologia. Wartość perfekcyjna nasuwa skojarzenie z perfekcjami, czyli rekwizytami w stopniu maksymalnym. Wartość perfekcyjna to nie jest więc wartość doskonała, raczej doskonałościowa - wartość w materii doskonałości. Jeśli — jak chciał Leibniz — wszystkie perfekcje są tylko w Bogu, w pozostałych monadach tylko niektóre i to nie we wszystkich, wartości perfekcyjne, których rekwizytami są perfekcje, stanowią w świecie rzadkość. Wysiłek osiągania doskonałości jest niełatwy, choć niebeznadziejny.

Nie chcemy twierdzić, że Elzenberg był leibnizjanistą ani że jego aksjologia jest monadologią. Chcemy jedynie obstawać przy przekonaniu, miejmy nadzieję na podstawie uprzedniego, trafnym, że mające miejsce podczas pisania Podstaw metafizyki Leibniza obcowanie Elzenberga z myślą Hanowerczyka sprawiło, że jego filozofowanie weszło Elzenbergowi w krew, w styl myślenia, że go ukształtowało o tyle, o ile przy oporach 'natury' w ogóle ukształtować go mogło. I że Elzenberg mógłby o Leibnizu powiedzieć, że należy do „tych wielkich, u których terminując stał się ich dziełem i tego, czego go nauczyli. I nie ma odwrócenia się od” Leibniza: ,jest wdzięczność"'44.

\section{Bibliografia}

Czeżowski T., Głos w dyskusji nad referatem M. A. Krąpca, „Znak” 130 (1965), s. $437-438$.

Elzenberg H., Kłopot z istnieniem. Aforyzmy w porządku czasu, Kraków 1963.

44 H. Elzenberg, Kłopot z istnieniem (9 VII 1961), s. 448. 
Elzenberg H. Konstrukcja pojęcia wartości, [w:] H. Elzenberg, Pisma aksjologiczne, L. Hostyński, A. Lorczyk, A. Nogal (oprac.), Lublin 2002, s. 71-95.

Elzenberg H., Motywacja etyczna (wartość w religii i kulturze), „Studia Filozoficzne 12 (1986), s. $13-18$.

Elzenberg H., Ogólność i oryginalność w sztuce. Gtębokość. Sztuka jako objawienie, [w:] H. Elzenberg, Pisma estetyczne, L. Hostyński (oprac.), Lublin 1999, s. 163-179.

Elzenberg H., Personalia stoickie i „ascetyczno-moralizatorskie”, [w:] H. Elzenberg, Pisma etyczne, L. Hostyński (oprac.), Lublin 2001, s. 115-155.

Elzenberg H., Podstawy metafizyki Leibniza, Kraków 1917.

Elzenberg H., Pojęcie wartości i powinności. Tekst żemłosławski, [w:] H. Elzenberg, Pisma aksjologiczne, L. Hostyński, A. Lorczyk, A. Nogal (oprac.), Lublin 2002, s. $123-168$.

Elzenberg H., Tragedia i tragizm, [w:] Księga szkiców, Rkps, Archiwum PAN, MHE III-181, w oryginalnym układzie Elzenberga teczka 19.

Elzenberg H., Wartość $i$ człowiek, Toruń 1966.

Elzenberg H., Zbawienie i ideat w moim ujęciu, Rkps, Archiwum PAN, MHE III-181, w oryginalnym układzie Elzenberga teczka nr 46.

Kowalik Ł., Historia braci polskich, „Przegląd Filozoficzny — Nowa Seria” R. 26: 2017, Nr 3(103), s. 245-266.

Leibniz G.W., Monadologia, tłum. H. Elzenberg, przygotował do druku M. Woroniecki, Toruń 1991.

Leibniz G.W., Polemika z S. Clarke'iem, tłum. S. Cichowicz, H. Krzeczkowski, [w:] Leibniz G.W., Wyznanie wiary filozofa, Warszawa 1969, s. 321-448, 510-518.

Leibniz G.W., Prawdy pierwotne metafizyki, tłum. J. Domański, [w:] G.W. Leibniz, Wyznanie wiary filozofa, Warszawa 1969, s. 89-94, 472-474.

Leibniz G.W., Rozprawa metafizyczna, tłum. S. Cichowicz, [w:] G.W. Leibniz, Wyznanie wiary filozofa, Warszawa 1969, s. 97-146, 474-486.

Leibniz G.W., Wyznanie wiary filozofa, tłum. J. Domański, [w:] G.W. Leibniz, Wyznanie wiary filozofa, Warszawa 1969, s. 3-56, 451-465.

Leibniz G.W., Wzorzec dowodów politycznych, tłum. T. Bieńkowski, Bydgoszcz 1992.

Lorczyk A., O nadwartości, powinności i sensie. Prolegomena rekonstrukcji późnej aksjologii Elzenberga, [w:] Człowiek wobec wartości w filozofii Henryka Elzenberga, A. Lorczyk (red.), Warszawa 1998, s. 93-130.

Okołowski P., Między Elzenbergiem a Bierdiajewem. Studium aksjologiczno-antropologiczne, Warszawa 2012.

Paź B., Rudymenty filozofii G. W. Leibniza w ujęciu H. Elzenberga. Wokół logikalnej interpretacji metafizyki Leibniza, [w:] Człowiek wobec wartości w filozofii Henryka Elzenberga, A. Lorczyk (red.), Warszawa 1998, s. 47-67.

Perzanowski J., Teofilozofia Leibniza, [w:] G.W. Leibniz, Pisma z teologii mistycznej, Kraków 1994, s. 243-351.

Wolniewicz B., Myśl Elzenberga, [w:] B. Wolniewicz, Filozofia i wartości, Warszawa 1993, s. 69-94.

Wolniewicz B., Z aksjologii Elzenberga, [w:] B. Wolniewicz, Filozofia i wartości, Warszawa 1993, s. 142-152. 
Studia Philosophica Wratislaviensia vol. XVI, fasc. 4, 2021 (c) for this edition by CNS 